of SLE patients were reported to suffer from severe infections ${ }^{1,2}$. However, due to the high cost of recruiting patients, we still do not have a holistic picture of the SLE-infection association. Administrative data which encompass all provincially funded healthcare service data shows promising opportunities to advance the knowledge and management of the SLE patients which cannot be evaluated by the conventional clinical setting with small sample size and selective samples ${ }^{3,4,5}$. Objectives: To evaluate the risk of severe infection and infection-related mortality among patients with newly diagnosed systemic lupus erythematosus.

Methods: We conducted an age- and gender- matched cohort study of all patients with incident SLE between January 1, 1997 and March 31, 2015 using administrative health data from British Columbia, Canada. Primary outcome was the first severe infection after SLE onset necessitating hospitalization or occurring during hospitalization. Secondary outcomes were total number of severe infections and infection-related mortality.

Results: We identified 5,169 SLE patients and matched them with 25,845 nonSLE individuals from the general population, yielding 955 and 1,986 first severe infections during 48,367 and 260,712 person-years follow-up, respectively. The crude incidence rate ratios for first severe infection and infection-related mortality were $2.59(95 \% \mathrm{Cl}, 2.39-2.80)$ and 2.20 (95\% Cl, 1.76-2.73), respectively. The corresponding adjusted hazard ratios were $1.82(95 \% \mathrm{Cl} 1.66-1.99)$ and 1.61 $(95 \% \mathrm{Cl}, 1.24-2.08)$. SLE patients had an increased risk of a greater total number of severe infections with crude rate ratio of $3.24(95 \% \mathrm{Cl}, 3.06-3.43)$ and adjusted rate ratio of $2.07(95 \% \mathrm{Cl}, 1.82-2.36)$.

Conclusion: SLE is associated with increased risks of first severe infection (1.8fold), a greater total number of severe infections (2.1-fold) and infection-related mortality (1.6-fold)

REFERENCES:

[1] Yurkovich M, Vostretsova K, Chen W, Aviña-Zubieta JA. Overall and cause-specific mortality in patients with systemic lupus erythematosus: a meta-analysis of observational studies. Arthritis Care Res (Hoboken) 2014;66(4):608-16.

[2] Petri M. Infection in systemic lupus erythematosus. Rheum Dis Clin North Am 1998;24(2):423-56.

[3] Cervera R, Khamashta MA, Font J, et al. Morbidity and mortality in systemic lupus erythematosus during a 10-year period: a comparison of early and late manifestations in a cohort of 1,000 patients. Medicine (Baltimore) 2003;82(5):299-308

[4] Goldblatt F, Chambers S, Rahman A, Isenberg DA. Serious infections in British patients with systemic lupus erythematosus: hospitalisations and mortality. Lupus 2009;18(8):682-9.

[5] Bosch X, Guilabert A, Pallares L, et al. Infections in systemic lupus erythematosus: a prospective and controlled study of 110 patients. Lupus 2006;15(9):584-9.

Disclosure of Interests: None declared

DOI: 10.1136/annrheumdis-2021-eular.17

\section{OP0044 ANA POSITIVITY IS ASSOCIATED WITH COMPLEX IMMUNE DISTURBANCE EVEN IN INDIVIDUALS WHO DO NOT DEVELOP CLINICAL AUTOIMMUNE DISEASE}

S. U. Hassan ${ }^{1,2}$, Z. Wigston ${ }^{1}$, A. Burska ${ }^{1}$, M. Y. MD Yusof ${ }^{1,2}$, E. Vital ${ }^{1,2} .{ }^{1}$ Leeds Institute of Rheumatic and Musculoskeletal Medicine, Rheumatology, Leeds, United Kingdom; ${ }^{2}$ NIHR Leeds Musculoskeletal Biomedical Research Centre, Leeds Teaching Hospitals NHS Trust, Leeds, United Kingdom

Background: Study of pre-clinical autoimmunity can reveal immune changes that initiate or prevent clinical disease. We previously reported an At Risk cohort of ANA positive individuals referred to secondary care, of whom $16 \%$ progressed to SLE or Sjogren's syndrome during follow up[1]. Recently, we also reported that even ANA positive individuals who do not develop clinical autoimmunity, have defective pDC function and non-haematopoietic interferon-production[2].

Objectives: To describe the immunophenotype of ANA-positive progressors and non-progressors compared to healthy controls.

Methods: We conducted a prospective observational longitudinal study of At-Risk individuals in Leeds $(n=150)$ over 3 years with annual follow up. Those who met classification criteria for autoimmune connective tissue disease (Al-CTD) during follow up were termed progressors and others; non-progressors. Among the non-progressors, those with no clinical diagnostic criteria at any time point were called absolute non-progressors (ANP).

At baseline we analysed two IFN-stimulated gene expression scores previously described[3] and flow cytometry performed for major circulating subsets. Association between progression group and biomarkers were tested using independent samples t-test.

Results: 3 year follow up data were available in 148/150 patients. Outcomes were: progressors: $30 / 148$ (20\%) [SLE=25; pSS=5] and non-progressors: $118 / 148$ (80\%). Within the non-progressors, 69/148 (47\%) were ANP.
A detailed analysis of baseline biomarkers is included in Table 1. Despite not developing clinically significant disease, non-progressors had significant alterations in several biomarkers. This was also evident in the ANP sub-group.

\section{Table 1.}

\begin{tabular}{|c|c|c|c|c|c|c|c|}
\hline Biomarker & $\begin{array}{l}\text { Healthy Controls } \\
\text { Mean } \\
(95 \% \mathrm{Cl})\end{array}$ & $\begin{array}{c}\text { Son- } \\
\text { progressors } \\
\text { Mean } \\
(95 \% \mathrm{Cl})\end{array}$ & $\begin{array}{c}\text { Difference } \\
\text { from } \\
\text { healthy } \\
\text { controls } \\
\mathrm{p}\end{array}$ & $\begin{array}{c}\text { Absolute non- } \\
\text { progressors } \\
\text { Mean } \\
(95 \% \mathrm{Cl})\end{array}$ & $\begin{array}{c}\text { Difference } \\
\text { from } \\
\text { healthy } \\
\text { controls } \\
\mathrm{p}\end{array}$ & $\begin{array}{l}\text { Progressors } \\
\qquad \begin{array}{c}\text { Mean } \\
(95 \% \mathrm{Cl})\end{array}\end{array}$ & $\begin{array}{c}\text { Difference } \\
\text { from } \\
\text { healthy } \\
\text { controls } \\
\mathrm{p}\end{array}$ \\
\hline $\begin{array}{l}\text { IFN } \\
\text { score A }\end{array}$ & $\begin{array}{c}-6.27 \\
(-6.88,-5.65)\end{array}$ & $\begin{array}{c}-5.22 \\
(-5.64,-4.80)\end{array}$ & 0.016 & $\begin{array}{c}-5.11 \\
(-5.91,-4.32)\end{array}$ & 0.120 & $\begin{array}{c}-4.14 \\
(-5.11,-3.18)\end{array}$ & 0.001 \\
\hline $\begin{array}{l}\text { IFN } \\
\text { score B }\end{array}$ & $\begin{array}{c}-5.43 \\
(-6.00,-4.85)\end{array}$ & $\begin{array}{c}-5.30 \\
(-5.62,-4.98)\end{array}$ & 0.193 & $\begin{array}{c}-4.96 \\
(-5.45,-4.47)\end{array}$ & 0.949 & $\begin{array}{c}-4.27 \\
(-4.90,-3.65)\end{array}$ & 0.136 \\
\hline $\begin{array}{c}\% \text { Mono- } \\
\text { cytes }\end{array}$ & $\begin{array}{c}14.80 \\
(10.50,19.11)\end{array}$ & $\begin{array}{c}15.46 \\
(12.96,17.97)\end{array}$ & 0.187 & $\begin{array}{c}14.94 \\
(11.42,18.47)\end{array}$ & 0.738 & $\begin{array}{c}10.36 \\
(7.42,13.30)\end{array}$ & 0.227 \\
\hline $\begin{array}{l}\% \text { CD4 } \\
\text { T cells }\end{array}$ & $\begin{array}{c}62.90 \\
(57.75,68.05)\end{array}$ & $\begin{array}{c}64.89 \\
(60.86,68.92)\end{array}$ & 0.001 & $\begin{array}{c}68.72 \\
(62.97,74.47)\end{array}$ & 0.267 & $\begin{array}{c}60.93 \\
(53.64,68.21)\end{array}$ & 0.001 \\
\hline $\begin{array}{l}\% \text { CD8 } \\
\text { T cells }\end{array}$ & $\begin{array}{c}32.18 \\
(27.47,36.90)\end{array}$ & $\begin{array}{c}28.60 \\
(25.12,32.09)\end{array}$ & 0.135 & $\begin{array}{c}25.02 \\
(20.28,29.77)\end{array}$ & 0.044 & $\begin{array}{c}31.51 \\
(25.63,37.40)\end{array}$ & 0.875 \\
\hline $\begin{array}{c}\% \text { Naïve } \\
\text { B cells }\end{array}$ & $\begin{array}{c}65.59 \\
(56.56,74.61)\end{array}$ & $\begin{array}{c}73.74 \\
(70.02,77.46)\end{array}$ & 0.001 & $\begin{array}{c}76.86 \\
(72.21,81.51)\end{array}$ & 0.128 & $\begin{array}{c}68.8660 .62 \\
75.84)\end{array}$ & 0.173 \\
\hline $\begin{array}{c}\% \text { Memory } \\
\text { B cells }\end{array}$ & $\begin{array}{c}29.56 \\
(20.42,38.72)\end{array}$ & $\begin{array}{c}19.72 \\
(15.84,23.61)\end{array}$ & $<0.000$ & $\begin{array}{c}23.13 \\
(16.65,29.61)\end{array}$ & 0.054 & $\begin{array}{c}25.57 \\
(17.18,33.96)\end{array}$ & 0.163 \\
\hline $\begin{array}{l}\% \text { Plasma- } \\
\text { blasts }\end{array}$ & $\begin{array}{c}1.12 \\
(0.81,1.43)\end{array}$ & $\begin{array}{c}0.91 \\
(0.58,1.24)\end{array}$ & 0.964 & $\begin{array}{c}1.01 \\
(0.44,1.58)\end{array}$ & 0.457 & $\begin{array}{c}0.81 \\
(0.53,1.10)\end{array}$ & 0.112 \\
\hline$\%$ NK cells & $\begin{array}{c}13.65 \\
(9.65,17.65)\end{array}$ & $\begin{array}{c}12.30 \\
(8.90,15.71)\end{array}$ & 0.480 & $\begin{array}{c}12.35 \\
(6.65,18.05)\end{array}$ & 0.781 & $\begin{array}{c}11.90 \\
(8.65,15.14)\end{array}$ & 0.195 \\
\hline
\end{tabular}

Conclusion: Clinically benign ANA positivity is a complex immune state with many features seen in active SLE, including pDC exhaustion, keratinocyte interferon production and strong skin interferon score, increased blood interferon score, and disturbance of B cell subsets. These findings suggest that other factors are necessary for clinical disease, or that regulatory mechanisms stabilise autoimmunity. Further work in this cohort will address these questions.

\section{REFERENCES:}

[1] Md Yusof et al. Ann Rheum Dis 2018

[2] El-Sherbiny et al. Sci Rep 2018

[3] Psarras et al. Nat Commun. 2020

Disclosure of Interests: Sabih-UI Hassan: None declared, Zoe Wigston: None declared, Agata Burska: None declared, Md Yuzaiful Md Yusof: None declared Edward Vital Grant/research support from: Honoraria and research grant support from Roche, GSK and AstraZeneca.

DOI: 10.1136/annrheumdis-2021-eular.1414

\section{\begin{tabular}{|l|l}
\hline OP0045 NLRP12 INVOLVES IN THE LUPUS WITH POSITIVE \\
\hline
\end{tabular} INTERFERON SIGNATURE}

Y. P. Tsao ${ }^{1}$, F. Y. Tseng ${ }^{2}$, C. W. Chao ${ }^{2}$, M. H. Chen ${ }^{1}$, S. T. Chen ${ }^{2} .{ }^{1}$ Taipei Veterans General Hospital, Division of Allergy, Immunology and Rheumatology, Department of Medicine, Taipei, Taiwan, Republic of China; ${ }^{2}$ National Yang-Ming University, Institutes of Clinical Medicine, Taipei, Taiwan, Republic of China

Background: Systemic lupus erythematous (SLE) is a systemic autoimmune disease with diverse etiological factors. It was recognized that interferon (IFN) signature involved in the progress of SLE. NLRP12 (NOD-like receptor family (NLR) pyrin domain containing 12) is a pyrin containing NLR protein that we had linked its new biological function to the cross-regulation of Toll like receptor (TLRs) and Rig-I like receptor (RIG-I) pathways. NLPR12 acts as an innate immune check-point in regulating type I IFNs expression during TLRs and RIG-I activation. The importance of NLRP12 in lupus disease activity remained to be elucidated.

Objectives: To clarify the role of NLRP12 in regulating the interferon signature. Methods: Peripheral blood mononuclear cells (PBMCs) were collected from SLE patients and healthy donors for analysis of NLRP12 and IFN- $\alpha$ gene expression by RT-QPCR. PBMCs were applied for Chromatin immuneprecipitation (ChIP assay and electrical mobility shift assay (EMSA) to determine the putative transcription factor that regulates NLRP12 expression. An involvement of epigenetic regulation of NLRP12 expression in SLE patients was also analyzed. Bone mar row derived dendritic cells (BMDCs) were collected from wild type mouse and Nirp12 knocked-out mice. Another CD14+ monocytes were isolated from 10 cases of lupus patients and 8 cases of healthy control, following by stimulating different type of nucleic acids, and IFN- $\alpha$ and IL- 6 were measured with ELISA assay. CD14+ monocytes in lupus patients were also pre-treated with IFNAR2 antibody for further nucleic acid stimulation. Two mice models were applied for evaluation the role of NIrp12: intraperitoneal injection of TMPD (2,6,10,14-tetramethylpentadecane, or pristane) in C57BL/6 mice and Fas ${ }^{\mathrm{lpr}}$ mice. Both models were conducted with and without Nlrp12 knockout. 